\title{
IMPROVING THE CONDITION OF EUROPEAN HARE THROUGH NUTRITION
}

\author{
MARTIN ERNST $^{1 *}$, PETR MADĚRA $^{2}$, TOMÁŠ FrANTÍK $^{2}$, JAN NOVÁK $^{3}$, \\ ŠTĚPÁN VENCL ${ }^{4}$
}

\author{
${ }^{I}$ Department of Forest Protection and Wildlife Management, Faculty of Forestry and Wood \\ Technology, Mendel University in Brno, Zemédělská 3, Brno, 613 00, Czech Republic \\ ${ }^{2}$ Department of Forest Botany, Dendrology and Geobiocoenology, Faculty of Forestry and \\ Wood Technology, Mendel University in Brno, Zemédělská 3, Brno, 613 00, Czech \\ Republic \\ ${ }^{3}$ Dibaq, a.s., Helvikovice 90, Žamberk, 564 01, Czech Republic \\ ${ }^{4}$ Veterinary office, Jirchářská 217, Kostelec nad Orlici, 517 41, Czech Republic \\ *Corresponding authore-mail: ernst@email.cz.
}

Received: $16^{\text {th }}$ April 2021, Accepted: $20^{\text {th }}$ April 2021

\begin{abstract}
The objective of the article is to evaluate the effects of a newly designed granulated mixture enriched with Bohemian knotweed (Reynoutria x bohemica) on European hare (Lepus europaeus) kept at closed farms. The positive influence of knotweed on the microbiome in the digestive system and better usage of the fodder were proven based on biochemical and haematological analysis of blood. Lower manifestation of pathogenic organisms is also expected. Finally, the positive influence on higher weight gains in baby hares was proven, which improves their condition. The results can be used in practice at closed farms breeding European hare focused on releasing bred young hares into open hunting grounds where it is possible to obtain a monetary contribution for the releasing of hares from a grant of the Ministry of Agriculture of the Czech Republic in the field of hunting. Furthermore, the results can be used for feeding hares in open hunting grounds.
\end{abstract}

Keywords: European hare; granulated feeding mixture; Bohemian knotweed; biochemical analysis of blood; haematological analysis of blood

\section{INTRODUCTION}

The nutrition of animals is the part of the overall regimen of animal care that requires expert knowledge of animals' biology and their physiological needs, as well as proper administration of fodder according to time and the needs of animals. Proper nutrition is an inseparable part of animal care and one of the key factors for achieving good condition and constitution and increasing the breeding quality of animals at closed farms and in the wild.

Kučera et al. (2006) rank hares among steppe and forest-steppe species that are predominantly found on field and forest edges in the cultural landscape. Hell \& Slamečka (1999) state that hare is an exclusive herbivore which feeds mainly on plant communities that are found in meadows and pastures. Based on the energetic balance, the need for fresh mass of hare was determined as $0.6-0.8 \mathrm{~kg}$. Hares prefer a diet consisting of a large number of 
herbs, field weeds, and agricultural crops (e.g. beet, cabbage, oilseed rape, pea, winter crops and permanent grassland). They also like woody plants (e.g. grapevine and fruit trees), which constitute about $5 \%$ of hares' diet. When there is sufficient food, hares are quite choosy, whereas in times of scarcity, they may suffer from a lack of quality food due to the monotrophic diet, which can lead to death. A sudden change in the species' structure of food may be the cause, for instance, due to the harvest of crops or tillage. The hare is an animal that is characterised by a relatively small active radius, and such a sudden change may be fatal for it due to the hectare areas that are routinely farmed at the same time. When looking for appropriate food, it goes a maximum of $1 \mathrm{~km}$ from its territory, which does not have to be enough to acquire a more varied diet. Moreover, it is necessary to realise that for digesting, hares use caecotrophy, which is consumption and repeated digestion of mushy excrement (caecotropes) which contains, among others, microorganisms that help in digesting plant food.

To understand all the contexts related to nutrition and animal feeding, it is necessary to state that our landscape and environment have changed significantly during the evolution. Natural biotopes are giving way to agriculture, which forces animals to adapt to constantly changing conditions. Large-area agricultural management to obtain higher yields has created a territory with very limited and poor sources of food and shelter from a landscape that was once rich and lively. The rapid process of cereal, forage and root crop harvest on large areas with subsequent tillage and cultivation of land causes a drastic change in the availability of natural food for animals.

For Bohemian knotweed (Reynoutria $\times$ bohemica), it is possible to assume similar positive effects that were described by several authors for Japanese knotweed (Polygonum japonicum, syn. Reynoutria japonica), which is also ranked among invasive plants. For resveratrol and piceid contained in the knotweed, antioxidation properties were proven, and piceid seems to be more effective than resveratrol (Jacob et al., 2014). Lawless (2010) states that daily administration of resveratrol improves energetic metabolism in horses by acting on mitochondria, which serve as a 'power station' of the body. In vitro tests on laboratory animals and clinical studies in human medicine show antibacterial effects (Chan, 2002; Docherty et al., 2001), antifungal effects (Adrian et al., 1997; Bavaresco et al., 2001, 2003; Filip et al., 2003; Jung et al., 2005; Schulze et al., 2005), antiparasitic effects (Anantaphruti et al., 1982), anti-cancer effects (Ferry-Dumazet et al., 2002; Roman et al., 2002; Ulrich et al., 2005; Wolter et al., 2004; El-Mowafy \& Alkhalaf, 2003; Lu et al., 2008; Muto et al., 2007; Fu et al., 2007; Pecere et al., 2000; Jeong et al., 2010; Pezzuto, 2008), and effects against vascular and other so-called diseases of civilisation, even those related to overweight and diabetes (Kerem et al., 2006; Dal-Pan et al., 2010; Brasnyo et al., 2011). Maděra et al. (2021) found positive effects of Bohemian knotweed in pig diet, especially on lipid metabolism.

The objective of the article is to evaluate the effects of a newly designed granulated mixture enriched with Bohemian knotweed (Reynoutria x bohemica) on European hare (Lepus europaeus) kept at closed farms.

\section{MATERIAL AND METHODS}

During a two-year period, a group of 14 European hares, to which the granulated feed mixture with the addition of knotweed was administered, and a control group of 8 European hares, to which the same feed mixture without the addition of knotweed was administered were tested. Throughout the whole experiment, breeding pairs of hares were kept together in special cotes for hares. The number of baby hares born to each breeding pair was monitored, 
and the birth weight and weight at 5 days of each baby hare were noted. At the end of the calendar year (after the end of the reproductive season and before the start of a new reproductive season), a veterinarian took blood from a vein in the auricle from all the alive individuals. Subsequently, the blood samples were biochemically analysed at Medila s.r.o. by MVDr. Štěpán Vencl, a veterinarian specialised in haematology. Values of ALT, AST, ALP, GMT, urea, creatinine, total protein, albumin, A/G ratio, globulins, glucose, triglycerides, cholesterol, $\mathrm{CK}$, bilirubin $\mathrm{T}$ and bilirubin $\mathrm{P}$ were determined biochemically; and values of leukocytes, erythrocytes, haemoglobin, haematocrit, $\mathrm{MCV}, \mathrm{MCH}, \mathrm{MCHC}$, neutrophiles, eosinophiles, basophiles, lymphocytes and monocytes were determined haematologically. The group fed with the addition of knotweed and the group fed without the addition were evaluated separately using statistical methods.

\section{RESULTS AND DISCUSSION}

Significantly different results between the group of hares fed a mixture with the addition of knotweed and the group of hares fed a mixture without the addition of knotweed were found in the content of urea and creatinine and the CK value. No statistically significant results were found in other monitored biochemical and haematological parameters, and therefore they are not described in detail here. For an overview, however, we present the range of measured values from biochemical and haematological analysis of blood from the entire period of the experiment in the following tables.

Table 1: The range of biochemical values measured within the monitored groups of hares

\begin{tabular}{|l|c|c|c|c|c|}
\hline \multirow{2}{*}{ Biochemical value } & \multirow{2}{*}{ Unit } & \multicolumn{2}{c|}{ The group with knotweed } & \multicolumn{2}{c|}{ The group without knotweed } \\
\cline { 3 - 6 } & & Min. & Max. & Min. & Max. \\
\hline ALT & $\mu \mathrm{kat} / \mathrm{l}$ & 0.51 & 2.92 & 0.70 & 1.14 \\
\hline AST & $\mu \mathrm{kat} / 1$ & 0.51 & 1.89 & 0.52 & 1.74 \\
\hline ALP & $\mu \mathrm{kat} / 1$ & 0.35 & 2.71 & 0.45 & 1.63 \\
\hline GMT & $\mu \mathrm{kat} / 1$ & 0.09 & 0.38 & 0.12 & 0.34 \\
\hline Urea & $\mathrm{mmol} / \mathrm{l}$ & 4.00 & 8.60 & 6.80 & 10.80 \\
\hline Creatinine & $\mu \mathrm{mol} / 1$ & 61.00 & 90.00 & 70.00 & 103.00 \\
\hline Total protein & $\mathrm{g} / \mathrm{l}$ & 45.00 & 55.60 & 45.30 & 55.00 \\
\hline Albumin & $\mathrm{g} / \mathrm{l}$ & 35.90 & 41.60 & 36.50 & 42.60 \\
\hline Globulins & $\mathrm{g} / \mathrm{l}$ & 7.20 & 14.40 & 7.20 & 13.40 \\
\hline A/G ratio & & 2.86 & 5.50 & 3.10 & 5.29 \\
\hline Glucose & $\mathrm{mmol} / 1$ & 8.68 & 14.95 & 9.75 & 16.20 \\
\hline Triglycerides & $\mathrm{mmol} / 1$ & 0.48 & 1.42 & 0.65 & 1.10 \\
\hline Cholesterol & $\mathrm{mmol} / \mathrm{l}$ & 0.36 & 0.71 & 0.37 & 0.63 \\
\hline CK & $\mu \mathrm{kat} / 1$ & 6.96 & 17.36 & 6.57 & 15.13 \\
\hline Bilirubin T & $\mu \mathrm{mol} / 1$ & & $<1.8$ & & $<1.8$ \\
\hline Bilirubin P & $\mu \mathrm{mol} / 1$ & & $<1.8$ & & $<1.8$ \\
\hline
\end{tabular}


Ernst M., Maděra P., Frantík T., Novák J., Vencl Š.: Improving the condition of European hare through nutrition

Table 2: The range of haematological values measured within the monitored groups of hares

\begin{tabular}{|l|c|c|c|c|c|}
\hline \multirow{2}{*}{ Haematological value } & \multirow{2}{*}{ Unit } & \multicolumn{2}{|c|}{ The group with knotweed } & \multicolumn{2}{c|}{ The group without knotweed } \\
\cline { 3 - 6 } & & Min. & Max. & Min. & Max. \\
\hline Leucocytes & $\times 10^{9} / 1$ & 1.60 & 7.20 & 3.40 & 8.20 \\
\hline Erythrocytes & $\times 10^{12} / 1$ & 9.28 & 11.40 & 9.00 & 10.18 \\
\hline Haemoglobin & $\mathrm{g} / 1$ & 183.00 & 211.00 & 180.00 & 201.00 \\
\hline Haematocrit & $1 / 1$ & 0.600 & 0.710 & 0.590 & 0.670 \\
\hline MCV & $\mathrm{fl}$ & 58.77 & 69.47 & 63.85 & 68.93 \\
\hline MCH & $\mathrm{pg}$ & 17.55 & 21.01 & 17.75 & 21.12 \\
\hline MCHC & $\mathrm{g} / 1$ & 284.85 & 314.52 & 268.66 & 316.13 \\
\hline Neutrophils seg. & $\times 10^{9} / 1$ & 0.372 & 3.264 & 0.578 & 4.428 \\
\hline Neutrophils seg. & $\%$ & 6.00 & 68.00 & 14.00 & 69.00 \\
\hline Eosinophiles & $\times 10^{9} / 1$ & 0.000 & 0.124 & 0.000 & 0.064 \\
\hline Eosinophiles & $\%$ & 0.00 & 5.00 & 0.00 & 1.00 \\
\hline Basophiles & $\times 10^{9} / 1$ & 0.000 & 0.032 & 0.000 & 0.000 \\
\hline Basophiles & $\%$ & 0.00 & 1.00 & 0.00 & 0.00 \\
\hline Monocytes & $\times 10^{9} / 1$ & 0.000 & 0.252 & 0.034 & 0.246 \\
\hline Monocytes & $\%$ & 0.00 & 7.00 & 1.00 & 3.00 \\
\hline Lymphocytes & $\times 10^{9} / 1$ & 0.896 & 5.616 & 1.856 & 6.004 \\
\hline Lymphocytes & $\%$ & 29.00 & 90.00 & 29.00 & 85.00 \\
\hline
\end{tabular}

A statistically significant result was observed in the change of urea concentration during two years, where the values found in blood of hares fed on a feeding mixture with the addition of knotweed were lower than in hares fed normally (see Fig. 1). Due to the fact that urea is created as a metabiological product during the degradation of amino acids, where the created ammonia is bound and excreted in the form of urea, it is possible to state, based on the results of comparing the groups fed with and without knotweed, that fodder with the addition of knotweed contributes to better usage of proteins that were further metabolised and used by the organism. According to the chemical analysis of the fodders, it can be assumed that there is enough protein in the fodder, urea is rather unspecific for liver functions. However, if we were looking for pathologies, it can be seen in the following figure that the same group also has higher creatinine (see Fig. 2), which would indicate a possible limitation in kidney function, but the values are within the physiological standard. Marco et al. (2008) state that the range of the amount of urea for European hare is 11.31-21.19 $\mathrm{mmol} / \mathrm{l}$, which are higher values than we have observed in both monitored groups. 
Fig. 1: The change of urea content during two years for hares fed on the feeding mixture with the knotweed addition and without the knotweed addition. Mean \pm S.D. Statistically different values at $\mathbf{P}=\mathbf{0 . 0 5}$ are marked with an asterisk.

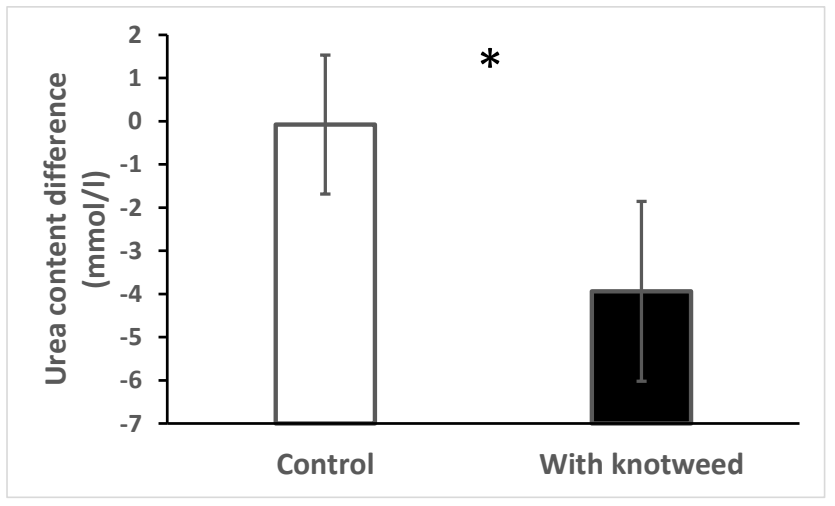

The higher interannual increase of creatinine in the blood of female hares fed on the feeding mixture without the addition of knotweed compared to the female hares fed on the mixture with the addition of knotweed is statistically significant. The opposite is true for males; however, no significant results were found (see Fig. 2). The creatinine concentration in serum is directly proportional to the muscle mass of the organism; consequently, it is slightly higher in male hares and lower in baby hares and with lower volume of muscle mass.

Fig. 2: The change of creatinine content during the year 2019 in hares fed on the feeding mixture with the knotweed addition and without the knotweed addition according to sex. Mean \pm S.D. Statistically different values at $P=0.05$ are marked with an asterisk.

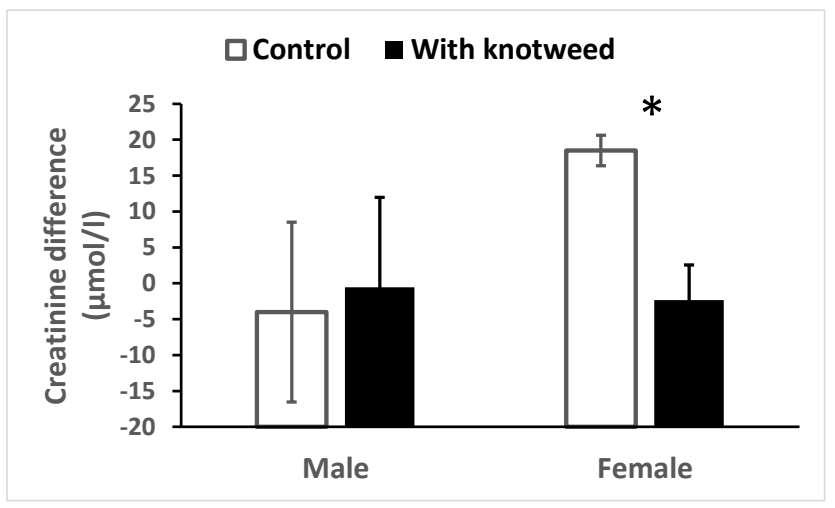

Higher values may also be found in the kidneys, for example, in the case of dehydration. The resulting values are relatively low, and therefore the physiology, the different age of animals and the state of their hydration may also have an impact here. Based on the results of the experiment, it can be assumed that a metabolism disruption occurred, probably caused by higher sensitivity to stress, in female hares fed on the mixture without the addition of knotweed, which may have affected the results. If we compare values we observed in individuals fed with the knotweed addition (61.00-90.00 $\mu \mathrm{mol} /)$ or without the addition of knotweed (70.00-103.00 $\mu \mathrm{mol} /$ ) with the results of Marco et al. (2008), who found values in 
the range of $87.4-140.6 \mu \mathrm{mol} / \mathrm{l}$, our range of values is lower while the lowest is for individuals fed on the feeding mixture with the addition of knotweed.

A statistically significant result was also found for the interannual difference of CK values, where a lower value was found in the blood of hares fed on the feeding mixture without the addition of knotweed compared to the hares fed on the mixture with the addition of knotweed (Fig. 3). CK is an important enzyme in the energetic metabolism of organisms. It is necessary to take into account the influence of age, volume of muscle mass and physical activity. In pathologies, it usually increases with muscle damage (together with AST and other indicators). Together with the observed lower values of urea and better weight gain in baby hares, the pathology is not expected, though better management of nitrogenous substances is more likely. Furthermore, the effect of manipulation-capture from breeding cotes is possible here, which increases the muscle work before the blood collection, and therefore a higher amount of enzyme could be released into the blood.

Fig. 3: The change of CK value during the year 2019 in hares fed on the feeding mixture with the knotweed addition and without the knotweed addition. Mean \pm S.D. Statistically different values at $\mathbf{P}=\mathbf{0 . 0 5}$ are marked with an asterisk.

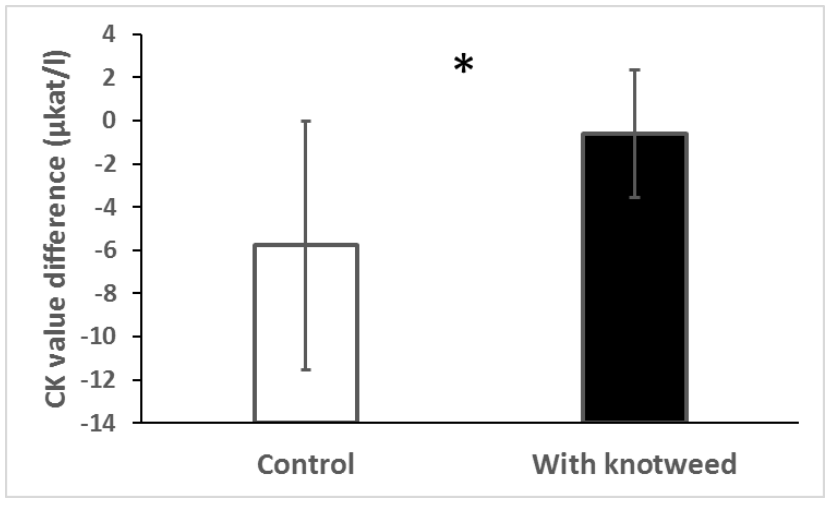

Fig. 4: The weight gain at 5 days after birth in baby hares from parents fed on the feeding mixture with the knotweed addition and without the knotweed addition. Mean \pm S.D. Statistically different values at $\mathbf{P}=\mathbf{0 . 0 5}$ are marked with an asterisk.

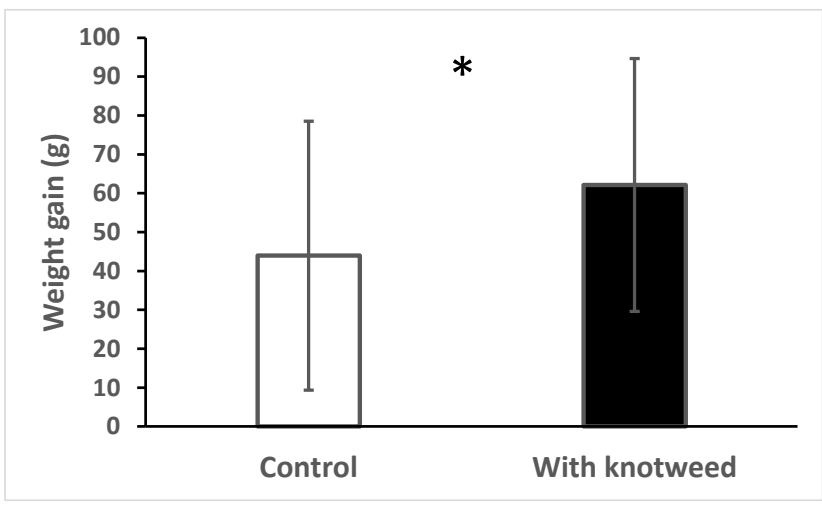


The final statistically significant result is the difference in the weight gain of baby hares from breeding pairs fed on the feeding mixture with the addition of knotweed compared to those from breeding pairs fed on the mixture without the knotweed addition (see Fig. 4).

This monitored parameter shows the proven manifestation of higher weight gain. The positive influence on the weight gain of baby hares from females fed on the feeding mixture with knotweed can be expected. Pregnant and lactating female hares have the highest demand for the protein content. If knotweed improved the protein usage, for example, by modifying the microbiome, this would be ideal since increasing the protein in hares is quite problematic due to the immediate reproduction of bacteria of the Clostridium spp. genus.

\section{CONCLUSION}

Following biochemical and haematological analysis, significant and different results between the group of hares fed on the mixture with the knotweed addition and the group of hares fed on the mixture without knotweed were observed in the urea and creatinine content and in the CK value. Based on the results, it is obvious that after the enrichment with knotweed, the feeding mixture has a positive influence on the microbiome in the digestive system and better usage of fodder in European hare. The lower manifestation of pathogenic organisms can be expected, and the positive influence on the weight gain of baby hares was proven, which improves their condition. For these reasons, the feeding mixture with the addition of knotweed is suitable for use mainly at closed farms that produce young European hare for releasing into the wild to improve the genetic variability in subpopulations or for the establishment of new subpopulations. However, it is also suitable for feeding Leporidae in open hunting grounds. Finally, the results obtained seem to indicate that it is suitable for use at backyard holdings and farms with rabbits, in which a similar effect can be expected. In conclusion, it can be stated that the observed results for hares fed on the feeding mixture with the addition of knotweed seem to be original, and therefore it was not possible to compare them with results of other authors.

\section{Landscape ecological implication}

Japanese knotweed (Reynoutria japonica), Sakhalin knotweed ( $R$. sachalinensis) and their hybrid Bohemian knotweed $(R . \times$ bohemica) are considered some of the most dangerous invasive plant species in the Czech Republic (Mandák et al., 2004) and in entire temperate zone of the Northern Hemisphere (Claude, 2017; Shaw et al., 2009; Luque et al., 2014). Utilisation of knotweed for fodder additive production could be way how to eradicate it at least partially from the landscape.

\section{ACKNOWLEDGEMENTS}

This work was supported by the project no. TH02010325 of the Technology Agency of the Czech Republic.

\section{CONFLICTS OF INTEREST}

The authors declare no conflict of interest. 


\section{REFERENCES}

Adrian, M., Jeandet, P., Veneau, J., Weston, L.A., Bessis, R., (1997). Biological activity of resveratrol, a stilbenic compound from grapevines, against Botrytis cinerea, the causal agent for gray mold. Journal of Chemical Ecology. 23(7): 1689-1702.

Anantaphruti, M., Terada, M., Ishii, A.I., Kino, H., Sano, M., Kuroyanagi, M., \& S. Fukushima (1982). Chemotherapy of parasitic helminths: 11. In vitro effects of various drugs on the motor activity of adult Schistosoma japonicum. JPN J Parasitol. 31(4): 321-328.

Bavaresco, L, Pezzutto, S, Ragga, A, Ferrari, F, Trevisan, M., (2001). Effect of nitrogen supply on trans-resveratrol concentration in berries of Vitis vinifera L. cv. Cabernet Sauvignon. Vitis. 40: 229-230.

Bavaresco, L., Vezzulli, S., Battilani, P., Giorni, P., Pietri, A., Bertuzzi, T., (2003). Effect of ochratoxin A-producing Aspergilli on stilbenic phytoalexin synthesis in grapes. Journal of Agricultural and Food Chemistry. 51(21): 6151-6157.

Brasnyo, P., Molnar, G.A., Mohas, M., Marko, L., Laczy, B., Cseh, J., Mikolas, E., Szijarto, I.A., Merei, A., Halmai, R., Meszaros, L.G., Sumegi, B., Wittmann, I., (2011). Resveratrol improves insulin sensitivity, reduces oxidative stress and activates the Aktpathway in type 2 diabetic patients. Br. J. Nutr. 106: 383-389.

Chan, M.M.Y., (2002). Antimicrobial effect of resveratrol on dermatophytes and bacterial pathogens of the skin. Biochem. Pharmacol. 63: 99-104.

Claude, L., (2017). The impact of invasive knotweed species (Reynoutria spp.) on the environment: review and research perspectives. Biological Invasions, 19 (8): 2319-2337. https://doi.org/10.1007/s10530-017-1444-y.

Dal-Pan, A., Blanc, S., Aujard, F., (2010). Resveratrol suppresses body mass gain in aseasonal non-human primate model of obesity. BMC Physiol. 10: 11.

Docherty, J.J., Fu, M.M., Tsai, M., (2001). Resveratrol selectively inhibits Neisseria gonorrhoeae and Neisseria meningitidis. J. Antimicrob. Chemother. 47: 243-244.

El-Mowafy, A.M., Alkhalaf, M., (2003). Resveratrol activates adenylyl-cyclase in human breast cancer cells: a novel, estrogen receptor-independent cytostatic mechanism. Carcinogenesis. 24: 869-873.

Ferry-Dumazet, H., Garnier, O., Mamani-Matsuda, M., Vercauteren, J., Belloc, F., Billiard, C., Dupouy, M., Thiolat, D., Kolb, J.P., Marit, G., Reiffers, J., Mossalayi, M.D., (2002). Resveratrol inhibits the growth and induces the apoptosis of both normal and leukemic hematopoietic cells. Carcinogenesis. 23: 1327-1333.

Filip, V., Plockova, M., Smidrkal, J., Spickova, Z., Melzoch, K., Schmidt, S., (2003). Resveratrol and its antioxidant and antimicrobial effectiveness. Food Chemistry. 83(4): 585-593.

Fu, Z.Y., Han, J.X., Huang, H.Y., (2007). Effects of emodin on gene expression profile in small cell lung cancer NCI-H446 cells. Chinese Medical Journal. 120(19): 1710-1715.

Hell, P., Slamečka, J., (1999). Hares. Biology, breeding and hunting in the agrarian landscape. 1st edition, Bratislava, PaRPRESS. ISBN 80-88789-47-8.

Jacob C., Kirsch G., Slusarenko A., Winyard P.G., Burkholz T., (2014): Recent Advances in Redox Active Plant and Microbial Products: From Basic Chemistry to Widespread Applications in Medicine and Agriculture. Springer; NJ, USA.

Jeong, E.T., Jin, M.H., Kim, M.S., Chang, Y.H., Park, S.G., (2010). Inhibition of melanogenesis by piceid isolated from Polygonum cuspidatum. Arch. Pharm. Res. 33: 1331- 
1338.

Jung, H.J., Hwang, I.A., Sung, W.S., Kang, H., Kang, B.S., Seu, Y.B., Lee, D.G., (2005). Fungicidal effect of resveratrol on human infectious fungi. Archives of Pharmacal Research. 28(5): 557-560.

Kerem, Z., Bilkis, I., Flaishman, M.A., Sivan, U., (2006). Antioxidant activity and inhibition of alpha-glucosidase by trans-resveratrol, piceid, and a novel trans-stilbene from the roots of Israeli Rumex bucephalophorus L. Journal of Agricultural and Food Chemistry. 54(4): 1243-1247.

Kučera, O., Kučerová, J., Havránek, F., (2006). Hare yesterday, today and tomorrow. 2nd edition, Uhlír̆ské Janovice, Silvestris. ISBN 978-80-901775-9-8.

Lawless, P., (2010). Two New Research Projects Study on Resveratrol's Effect on EMS. Retrieved September 30, 2013, from: Lexington, Kentucky: Biological Prospects/Equithrive; 2010.

Luque, G.M., Bellard, C., Bertelsmeier, C., Bonnaud, E., Genovesi, P., Simberloff, D., Courchamp, F., (2014). The 100th of the world's worst invasive alien species. Biol. Invasions, 16, 981-985. https://doi.org/10.1007/s10530-013-0561-5.

Lu, Y.Y., Zhang, J.L., Qian, J.M., (2008). The effect of emodin on VEGF receptors in human colon cancer cells. Cancer Biotherapy and Radiopharmaceuticals. 23(2): 222-228.

Maděra, P., Kovářová, M., Frantík, T., Filipčík, R., Novák, J., Vencl, Š., Maděrová, L., Rozkot, M., Kuchařová, S., Václavková, E., Truněčková, J., Volková, J., Nývltová, Z., Bartoš, M., (2021). Effect of Knotweed in Diet on Physiological Changes in Pig. Agriculture, 11, 169. https://doi.org/10.3390/agriculture11020169.

Mandák, B., Pyšek, P., Bímová, K., (2004). History of the invasion and distribution of Reynoutria taxa in the Czech Republic: a hybrid spreading faster than its parents. Preslia, 76 (1): 15-64.

Marco, I., Cuenca, R., Pastor, J., Velarde, R., Lavin S., (2008). Hematology and Serum Chemistry Values of the European Brown Hare. Veterinary Clinical Pathology. Wiley Online Library. https://doi.org/10.1111/j.1939-165X.2003.tb00335.x.

Muto, A., Hori, M., Sasaki, Y., Saitoh, A., Yasuda, I., Maekawa, T., Uchida, T., Asakura, K., Nakazato, T., Kaneda, T., Kizaki, M., Ikeda, Y., Yoshida, T., (2007). Emodin has a cytotoxic activity against human multiple myeloma as a Janus-activated kinase 2 inhibitor. Mol Cancer Ther. 6(3): 987-94.

Pecere, T., Gazzola, M.V., Mucignat, C., Parolin, C., Dalla, Vecchia F., Cavaggioni, A., Basso, G., Diaspro, A., Salvato, B., Carli, M., Palu, G., (2000). Aloe-emodin is a new type of anticancer agent with selective activity against neuroectodermal tumors. Cancer Research, 60(11): 2800-2804.

Pezzuto, J.M., (2008). Resveratrol as an inhibitor of carcinogenesis. Pharm. Biol. 46: 443573.

Roman, V., Billard, C., Kern, C., Ferry-Dumazet, H., Izard, J.C., Mohammad, R., Mossalayi, D.M., Kolb, J.P., (2002). Analysis of resveratrol-induced apoptosis in human B-cell chronic leukaemia. British Journal of Haematology. 117: 842-851.

Schulze, K., Schreiber, L., Szankowski, I., (2005). Inhibiting effects of resveratrol and its glucoside piceid against Venturia inaequalis, the causal agent of apple scab. J.Agr. Food Chem. 53: 356-362.

Shaw R., Bryner S., Tanner, R., (2009). The life history and host range of the Japanese knotweed psyllid, Aphalara itadori Shinji: Potentially the first classical biological weed 
Ernst M., Maděra P., Frantík T., Novák J., Vencl Š.: Improving the condition of European hare through nutrition

control agent for the European Union. Biological Control, 49 (2): 105-113. https://doi.org/10.1016/j.biocontrol.2009.01.016.

Ulrich, S., Wolter, F., Stein, J.M., (2005). Molecular mechanisms of the chemopreventive effects of resveratrol and its analogs in carcinogenesis. Molecular Nutrition \& Food Research. 49: 452-461.

Wolter, F., Ulrich, S., Stein, J., (2004). Molecular mechanisms of the chemopreventive effects of resveratrol and its analogs in colorectal cancer: Key role of polyamines? Journal of Nutrition. 134: 3219-3222. 